\title{
ON THE MOTIVATIONS FOR MERLEAU-PONTY'S ONTOLOGICAL RESEARCH
}

[Penultimate draft. For final version see British Journal for the History of Philosophy 26.2 (2018): 348-370.]

\author{
Dimitris Apostolopoulos
}

\begin{abstract}
This paper attempts to clarify Merleau-Ponty's later work by tracing a hitherto overlooked set of concerns that were of key consequence for the formulation of his ontological research. I argue that his ontology can be understood as a response to a set of problems originating in reflections on the intersubjective use of language in dialogue, undertaken in the early 1950s. His study of dialogue disclosed a structure of meaning-formation and pointed toward a theory of truth (both recurring ontological topics) that post-Phenomenology premises could not account for. A study of dialogue shows that speakers' positions are interchangeable, that speaking subjects are active and passive in varying degrees, and that the intentional roles of subjects and objects are liable to shift or 'transgress' themselves. These observations anticipate the concepts of 'reversibility' and 'narcissism,' his later view of activity and passivity, and his later view of intentionality, and sharpened the need to adopt an intersubjective focus in ontological research.
\end{abstract}

Keywords: Merleau-Ponty, Ontology, Language, Dialogue, Intersubjectivity

\section{§1. Introduction}

The texts associated with Merleau-Ponty's ontological projects pose significant interpretive difficulties. ${ }^{1}$ They introduce many new concepts, and propose different theoretical points of departure. ${ }^{2}$ The indeterminate character of his final work has motivated a wide range of scholarly interpretations of its key terms, especially 'the flesh' (la chair), a central tenet. Some scholars argue that Husserl's account of double-sensations in Ideen II exercised a decisive influence on Merleau-Ponty's turn to ontology (see Dastur 2000, 38-42; Moran 2010, 138; Richir 1998). Others emphasize the importance of Saussure's diacritical view of linguistic meaning (see e.g. Alloa 2009, Kearney 2013, Stawarska 2013). For some, the later ontology is anticipated by Phenomenology of Perception; but it is also argued that it is a genuinely new development. ${ }^{3}$ Heidegger, for example, has been identified as a positive and a negative influence on MerleauPonty's later work. ${ }^{4}$

To complicate matters further, Merleau-Ponty's philosophical modus operandi undermines the explanatory adequacy of any interpretation that emphasizes a single argument, concept, or interlocutor. His often fragmentary remarks, suggestive arguments, and tentative plans support multiple and sometimes conflicting interpretations of his ontology, making even its basic motivations difficult to discern. For example, he often defines the flesh in terms of the

\footnotetext{
${ }^{1}$ For influential studies see Madison 1981, Dillon 1988, Dastur 2000, Barbaras 2004, de Saint Aubert 2004, 2005. ${ }^{2}$ Abbreviations: Phenomenology of Perception $=$ PhP; The Prose of the World=PW; SNS=Sense and Non-Sense; Institution and Passivity=IP; The Visible and the Invisible=VI; Signs $=S ; N C=$ Notes de cours; Husserl at the Limits of Phenomenology=HLP; PrP=The Primacy of Perception; $P D=$ Parcours Deux; MSME=Le monde sensible et le monde de l'expression. I cite the most recent English translations (occasionally modified) and the French original, respectively. All translations of Prose of the World are mine. Citations to unpublished work refer to the manuscript volume and pagination of the Bibliothèque Nationale de France.

${ }^{3}$ For the former see Dillon 1988 174; for the latter see Madison 1981, 231-232; see also Butler 2005.

${ }^{4}$ See Lawlor 1999, Robert 2005, but $c f$. Noble 2014 222-228, Barbaras 2004, 305.
} 
double sensations felt in the experience of one hand touching the other. ${ }^{5}$ But he also claims that the flesh (and its characteristic 'reversibility') is not material, denying that it can be understood in any literal sense. ${ }^{6}$ He also claims that the flesh and the structure of perception are 'diacritical', pointing to Saussure's influence (VI 206/256, 213-214/263-264, 224/273, 233/282), while also identifying affinities and dissimilarities between his project and Heidegger's thought $(c f$. NC 123-124 with HLP 51/63). These remarks seem to equally support mutually incompatible lines of interpretation.

This paper attempts to clarify Merleau-Ponty's later work by tracing a hitherto overlooked set of concerns that I will argue were of key consequence for the formulation of his ontological research. Rather than defending a strong view about the meaning of concepts central to his ontology, I hope to shed light on its basic goals by offering a philosophical etiology of why he shifted the thematic focus of his research after the Phenomenology.

I will argue that Merleau-Ponty's ontology can be understood as a response to a set of problems originating in reflections on the intersubjective use of language in dialogue, undertaken in the early 1950s. His study of dialogue disclosed a structure of meaning-formation and pointed toward a theory of truth (both recurring ontological topics) that his post-Phenomenology premises could not adequately account for. While Merleau-Ponty's early writings relied on a subject-centric account of perception, meaning, and intentionality, the nature of expression and understanding in dialogue sharpened the need to adopt an intersubjective approach.

I begin with an overview of the aims of Merleau-Ponty's later projects, which reveals a consistent focus on the topics of sense, truth, and being. Evidence shows that this research was motivated by considerations originating in intersubjectivity $(\$ 2)$. A look at the structure of meaning-formation in dialogue brings this intersubjective focus into further relief: dialogue shows that speakers' positions are interchangeable ( $\$ 3.1)$; that speaking subjects are active and passive in varying degrees $(\$ 3.2)$; and that the intentional roles of subjects and objects are liable to shift or 'transgress' themselves (§3.3). These observations motivate Merleau-Ponty to revise his existing premises, and anticipate, respectively, the concepts of 'reversibility' and 'narcissism,' his later view of activity and passivity, and his final view of intentionality. Despite the implicit ontological import of this research, I show that he was already aware of its broader implications (\$4). I conclude by noting that this interpretation clarifies the importance of the philosophy of language for his later thought, and provides reasons to doubt that there is a conceptual break between his early and late work $(\$ 5)$.

\section{§. Ontology, Sense, and Intersubjectivity}

Early in The Visible and the Invisible, the general goal of Merleau-Ponty's later research is clearly identified: '[w]e want to know precisely what the meaning [le sens] of the world's being is' (VI 6/2; see also 96/129). ${ }^{7}$ His 'point of departure' is the observation that 'there is being, there is a world, there is something; ...there is cohesion, there is meaning [sens]' (88/119; translation modified). On the final page of the incomplete manuscript, he claims that philosophy

\footnotetext{
${ }^{5}$ MSME 118, 203-204; VI 9/24, 133-134/173-174, 146/187-188; BNF Ms. Vol. VI 172/13, $174 \mathrm{v} / 18$.

${ }^{6}$ VI 146-147/189-190. See also VI 153/198, 125/164, 138/179, 155/201, cf. 221-222/271; NC 202.

${ }^{7}$ See Morris 2010, and Jean Hyppolite's remarks on the link between sense and ontology (PrP 39/97-99).
} 
aims to facilitate the 'birth of meaning' (155/201). At a highest level of generality, ontology attempts to understand our meaningful experience of the world.

The goal of an inquiry into sense is a consistent theme running throughout his later projects. ${ }^{8}$ This connection is perhaps most evident in remarks about Origine de la vérité, the project Merleau-Ponty started drafting shortly after publishing the Phenomenology. It sought 'to give a precise description of the passage of perceptual faith into explicit truth as we encounter it on the level of language, concept, and cultural world' (SNS 94 n.13/188 n.1). ${ }^{9}$ Research notes from 1955-1956 associated with 'The Origin of Truth' also identify the need for a 'study of perceptual meaning as tacit meaning, by distance, constitution of existentials or "pivots," identity of consciousness and non-consciousness--(I know and I do not know the true)' (BNF Ms. Vol. VIII 126). In what will later become a standard formulation, this remark defines meaning across the 'distance' (écart) between perceivers. Instead of relying on 'consciousness,' or overly theoretical, subject-centric accounts, phenomena must be analyzed with reference to conditions that do not depend on the subject, or which the subject may be unaware of (hence the claim about 'tacit' meaning and 'unconsciousness').

While these formulations populate Merleau-Ponty's later texts, a similar observation in the 1955 Collège de France Passivity course sheds light on their original motivations. These lectures offer one of the earliest explicit formulations of the goals of ontological research. They make familiar refrains against the supposedly reigning 'objectivist ontology' of Western thought, i.e., the underlying assumption that exclusive categories (e.g. 'being' versus 'non-being') are necessary and sufficient to clarify the meaning of experience and perceptual objects (IP 133/178). Instead, one must develop an 'expanded ontology,' whose categories will be more varied. This will better clarify central ontological concerns like truth, subjectivity, and freedom (133-134/179).

Of key consequence are the success conditions for this research. To understand truth or the 'logos of the perceived world,' subjectivity must be at the heart of sense-making and understanding ('that the subject be that without which nothing has sense'). But it must be combined with a 'lateral relation' that 'relativizes [its] Sinngebung' (135/181). ${ }^{10}$ In other words, a subject's explicit, active sense-making capacities are no longer sufficient for an analysis of sense. Was this not partly what Merleau-Ponty credited himself with accomplishing in the Phenomenology? Evidently, earlier self-critical remarks suggest that he thought he had not gone far enough (MSME 45-56). Commentators have argued that the Phenomenology's theoretical dependence on subjectivity leads to an idealistic point of view (Barbaras 2004, 14-17/33-36). Counter-examples to this reading can certainly be marshalled, and even if one rejects this interpretation, it is difficult to ignore passages arguing that subjectivity is the ultimate

\footnotetext{
${ }^{8}$ See Être et sens, ou: La Généalogie du vrai (1958) $(2 / 1 ; 18 \mathrm{r} / 1)$, which links sense with 'truth,' 'being', and 'ontology' (4/2, 4v/3, 5v/5, (11r; 18r/1). See also La nature ou le monde de silence (de Saint Aubert 2008, 44-53) and Être et Monde (VI 198/248).

${ }^{9}$ See VI 165/217; 166/218; 168/219-220 and unpublished references (January 1959: BNF Ms. Vol. VIII 273; February 1959: 255/75a; and an undated remark 308/86a).

${ }^{10}$ For later uses of this term see MSME 205; PW 142/197; IP 61/103; VI 78/108, 102/137, 125/164, 143/186.
} 
explanatory term for any meaningful phenomenon. ${ }^{11}$ As he now stresses, constitution always presupposes the efforts of others (see Bonan 2001, Chapter 5).

This observation leads to a key condition, namely, that sense is

divergence [écart] between two or more perspectives [...]. If sense is this,...then whether it is "natural" (from perception) or "cultural" (from thought), "passive" or "active," in any case it is never a pure act of the subject; [it is] inconceivable without the perspectives between which it is outlined, belonging to the things as much as to me, taken up but not created by me--Sense [is] like determinate negation, a certain divergence [écart]; it is incomplete in me, and it is determined in others. The thing, the sensible world, are only ever completed in others' perception.... (136/182)

Put differently, perceptual meaning is formed across the views of multiple perceivers; it is not the domain of any single subject. In ontology, meaning must be defined intersubjectively. This does not obviate the role of subjective activity, but requires that the perspectives of other subjects are always part of an account of sense constitution. By extension, if 'the object is...also provided with a double horizon by means of which it can become the object for others and not for me alone,' then 'Being [is not] what is in itself or for someone, but what, being for someone, is ready to be developed according to another becoming of knowledge...' (61/103). Like 'sense' and 'truth,' 'being' must also be worked out with reference to intersubjectivity, since it can can be variously understood according to different perspectives (MSME 45-51, 53).

Merleau-Ponty's remarks during his candidature for the Collège de France (1951-1952) also identify the central role of intersubjectivity for ontology. L'origine de la vérité's investigations into truth were approached 'less directly,' he claimed, in Prose of the World $(P r P$ $8 / P D 44)$. While his 'first two works sought to restore the world of perception,' those 'in preparation aim to show how communication with others, and thought, take up and go beyond the realm of perception that initiated us to the truth' $(3 / 37)$. This evidence indicates that intersubjective communication is especially important for an analysis of truth, and that it cannot be reduced to earlier analyses of perception. It also signals the importance of The Prose of the World's account of intersubjectivity, which I now turn to.

\section{§3. The Implicit Ontological Implications of Dialogue}

In this section, I argue that Merleau-Ponty's guiding assumption that sense must be analyzed in light of intersubjectivity was motivated by research into the structure of dialogue. This research provided an early testing ground for concepts that would become central for his ontology. I call attention to three claims in particular: that speakers' positions in a dialogue are reversible (\$3.1); that dialogue requires a reformulated account of activity and passivity $(\$ 3.2)$; and that dialogue supports a relation of intentional 'encroachment' or 'transgression’ (\$3.3).

\footnotetext{
${ }^{11}$ See $e . g$. the claim that 'I am the absolute source' (PhP lxxii/9). The Phenomenology's explanatory structure also suggests a reliance on subjectivity, insofar as temporality, which is ultimately invoked to explain preceding analyses, turns out to be subjectivity itself (444-445/483-484).
} 
While the topic of intersubjective communication was partly discussed in the Phenomenology, Merleau-Ponty devotes increasing attention to it in subsequent writings and lecture courses. ${ }^{12}$ The most sustained philosophical analysis of dialogue in this period, which also integrates conclusions from other discussions, is found in Chapter 5 of Prose of the World. At the beginning of this chapter, Merleau-Ponty repeats earlier arguments against the plausibility of formal languages, and reconsiders the expressive power of literary language $(P W 3 / 7 \mathrm{ff}$. $)$. Nonformal modes of expression claim to reveal the true nature of objects. But the transformation of meaning they effect can be fully grasped 'only when we understand it as the trespass of oneself upon the other and of the other upon me...' (133/185).

It has been noted that there is a 'nascent ontology' and an 'ontological weight' in communication. ${ }^{13}$ However, these claims are often interpreted as 'paradigmatic' instances of the kind of embodied 'performances' described since The Structure of Behaviour (Landes 2013, 135). In other words, the ontological import of speech is usually understood as a product or version of the broader ontological implications of embodiment. Correlatively, the distinctively linguistic characteristics of dialogue are often traced to Merleau-Ponty's reading of Saussure. ${ }^{14}$ As I argue, however, dialogue has an ontological import of its own, which extends beyond the framework of embodiment. Further, the ontological implications of speech considered below are not informed by Saussurean tenets. ${ }^{15}$ The evidence I present suggests that we must look elsewhere to explain the development of Merleau-Ponty's ontology. Even if artists and linguists (including Saussure) demonstrate that language teaches us something new about the world, the meaning-transformation at work in dialogue is ultimately of greater philosophical consequence.

\subsection{Reversibility and Narcissism}

The claim that perception is 'narcissistic', and the view that the relation between subjects and objects is 'reversible', are key tenets of Merleau-Ponty's later work. ${ }^{16}$ Both are anticipated in reflections on dialogue.

Merleau-Ponty claims that dialogue is not, upon scrutiny, a 'face to face' exchange $(133 / 185)$. He does not mean that in dialogue we do not see another person before us. We perceive others' gestures, hear their voice, see the position of their body, etc.. His deeper point is that dialogue is not structured according to an alternating correspondence between two isolable, self-reliant terms. Instead, dialogue establishes a relation with another person that makes it difficult to say that 'I' am 'here' and 'my interlocutor' is 'there'.

\footnotetext{
${ }^{12}$ See PhP 370/412, the 1947 course Communication et Langage (Silverman 1979, 95-107), and analyses of dialogue in Child Psychology and Pedagogy.

${ }^{13}$ See Landes 2013, 135. See also Robert 2005, who claims that dialogue offers a 'first sketch of the idea of flesh,' without further developing this observation (151-156).

${ }^{14}$ See e.g. Landes 2013, 134; Bonan 2001 §17, 252, 342; Thierry 1987, 69-81; Stawarska 2013; Kearney 2013.

${ }^{15}$ Saussure certainly paves the way for a study of speech (22-23/33), but Merleau-Ponty also credits this to Husserl and the Dutch linguist Hendrik Pos (25/37). More broadly, textual support in Saussure's Course for Merleau-Ponty's conclusions about the diacritical nature of meaning is hard to come by: an unrelated reference to the diacritical occurs once (Saussure 2006, 76), and Merleau-Ponty does not quote from unpublished material ( $c f$. VI 175/227). ${ }^{16}$ For the former see VI 139/181, 141/183, 249/297; for the latter VI 133-135/173-176, 144/187. See Hughes 2016 for a recent account of reversibility.
} 
This claim is motivated by the observation that attempts to understand another speaker often leave us at a loss as to what they are claiming or suggesting. For Merleau-Ponty, this is not a mere failure of understanding, which could be explained by inopportune expressions, argumentative uncertainty, or lack of clarity. Instead, dialogical experience is an 'alliance' that establishes a shared relation between two (or more) participants (134/186). In dialogue a speaker's position is under continuous revision: we give and take, moving from one claim to another, and our positions continually shift. A shift in our stance can motivate a corresponding change in another subject's viewpoint. This entails that we do not confront an isolable speaker in an immutable place (unless, of course, one defines communication in perceptual or physical terms; Merleau-Ponty rejects this approach). The fact that speakers presuppose historically transmitted or 'sedimented' background meanings (syntax, word-meaning, concepts) that they do not invent further suggests that dialogue cannot be understood as an exchange between two selfsufficient subjects (PhP 189/224, 192/227; S 86/140 95/156).

These observations have important consequences for the philosophical status of subjectivity. If another subject also establishes and sustains the dialogical relation, the content of our contributions will also be formulated by our dialogical peer(s). Expression is only possible if another subject is present. Now this observation (like others above) might seem obvious, insofar as it is part and parcel of dialogue. Indeed, at this stage, the stronger conclusions Merleau-Ponty draws chiefly pertain to his extant account of sense and subjectivity, and are less focused on articulating an independent or wholly new theory of communication. Broader consequences for our understanding of dialogue as such can be drawn out by focusing on tenets like perceptual 'narcissism,' developed in more detail in later work; but these are beyond the scope of this paper. Still, Merleau-Ponty provides a striking account of dialogical experience:

How can the 'I think' emigrate beyond me, since it is me? The looks with which I scan the world...are seized by someone at the other end and sent back to touch me in turn. It is no longer enough for me to feel: I feel that someone feels me, that he feels me while I feel, while I feel the very fact that he feels me... . It is not enough simply to say that henceforth I inhabit another body: that would only make a second me, a second dwelling for me. But there is a myself which is other, which lies elsewhere and deprives me of my central location, though, by all accounts, he cannot draw on this capacity except through his filiation with me. The roles of the subject and of what it sees are exchanged and reversed [s'échangent et s'inversant]: I thought I gave to what I see its meaning as a thing seen, and then one of these things suddenly slips out of this condition; the spectacle comes to itself establish a spectator who is not I but who is reproduced from me. How is that possible? How can I see something that begins to see? $(P W 134-135 / 187)$

A basic conclusion from this passage is that dialogical speech undermines the hitherto central role of subjectivity. Dialogical expression shows that an ostensible spectator actually exercises significant demands on us, which we must respond to. The passage works out these demands in a perceptual, rather than a linguistic, register. But Merleau-Ponty's conclusion that the adequacy and self-sufficiency of a constituting subject is upset follows from the distinctively linguistic character of dialogue. In dialogue, the subject cannot be the sole arbitrator of sense, since the 'thing' we are directed to (our conversational partner) eventually co-determines the meaning of what is said or seen. And because the meaning we express in a discussion soon becomes the 
object of another subject's evaluations, dialogue shows that subjects can take on the status of objects or things seen.

These observations anticipate two fundamental claims in Merleau-Ponty's ontology: the 'reversibility' of subject-object relations, and the claim that perception is 'narcissistic.' Consider reversibility first. While he does not use the term 'réversibilité', Merleau-Ponty suggests that dialogue establishes a structural relation of reversibility between subject and object. A speaker can guide the flow of conversation, but they can also pass to the status of object while receiving the contributions of others. Speaker and listener exchange and effectively substitute their roles. A contemporaneous article notes that speech is a prime example of engagements that 'reverse [renversent] my ordinary relation to objects and give some of them the value of subjects' ( $S$ 94/153).

Even if this is not quite the mature account of reversibility, the basic position is offered in outline.${ }^{17}$ Later texts claim that a reversibility between seeing and object seen, touching and object touched, etc., defines 'the flesh', a term used to describe the basic structure of experience. This relation generalizes to a wide range of objects and domains (VI 144/187). In The Visible and the Invisible, Merleau-Ponty argues that there is a 'reflexivity' in speech of the same order as that in touch and sight (144/187-188). In a note from December 1959, he reproduces an earlier description of speech: '[t]he others' words make me speak and think because they create within me an other than myself, a divergence [écart] by relation to... what I see...' (224/273). He retains a link between reversibility and dialogue in later work, and uses the important term écart to describe the 'second self' that emerges in dialogue. Still more importantly, Prose of the World advances an account of reversibility that is not antedated by other texts in Merleau-Ponty's corpus, at least until $c a .1952$.

In addition to reversibility, the remarks above anticipate the claim that perception is 'narcissistic,' a related tenet. In The Visible and the Invisible, this term is used to capture the seamless contact between subjects and perceptual objects. As he puts it, 'since the seer is caught up in what he sees, it is still himself he sees: there is a fundamental narcissism of all vision' $(139 / 181)$. His point is not that perception is always reflexive, as if we only ever saw ourselves. Rather, subjects are so bound up with objects in everyday experience, making seamless contact with meanings in their world, that it seems as if the meanings and objects encountered are tailored specially to them; alternatively, that perceivers' positions are reflected back to them by perceptual objects.

Despite appearances, this view does not lead to a solipsistic, introspective account of perception (141/183). In pre-theoretical experience, subjects do not standardly oppose themselves to a world of determinable objects. Our everyday frequenting of the world makes it seem as if objects themselves offer meanings to us. Perception is an intimate connection to the world, which teaches us something about our intentional stance toward it. For Merleau-Ponty, perception is less of a deliberate engagement, and more like a passive openness to ourselves through our relation to objects. This is a key feature of his account of dialogue, and is reflected in the claim that a dialogical partner is also a quasi-self, rather than an inert, determinable object.

\footnotetext{
${ }^{17}$ For relevant differences see $P W 18 / 28,135 / 187,136 / 188$.
} 
While it might seem that we speak to an inert object, who receives the meaning of our speech, we soon learn that this object also exercises demands on us, modifying our conversational contributions. Accordingly, at the end of the account of dialogue, Merleau-Ponty asks: '[h]ow can I see something that begins to see?' (PW 135/187).

As in the later account of narcissism, his point is not that I speak to or see a mere copy of myself. The long passage quoted above shows that a relation in which I begin to see another subject as myself is only possible if another speaker mitigates the centrality of my position. We encounter a being similar to us, which reflects our stance, insofar as we detect conversational demands that are a response to our interventions, and insofar as we read the effects of our contributions in the responses issuing from our partner. The claim that perception is narcissistic aims to make just this point: we see ourselves in perceptual objects because we recognize a structure of perceptual solicitation that is a response to our highly particular intentional stance.

Even if one accepts that these observations anticipate reversibility or narcissism, it is also true that the Phenomenology defines intersubjective communication as a 'taking up of the other person's thought, a reflection in others, a power of thinking according to others' (PhP 184/218219). This characterization allows that dialogue unfolds according to the co-determination or 'reflection' of speakers' conversational stances. The Phenomenology also anticipates the claim that dialogue is a shared 'alliance.' In dialogue 'a common ground is constituted between me and another', and our thoughts 'form a single fabric.' Perhaps most importantly, by claiming that communication is 'a shared operation of which none of us is the creator', and that speaker and listener are 'collaborators in perfect reciprocity', this text hints at the need to reconsider the central role of subjectivity, a deeper theoretical consequence of Prose of the World (370/412; see also 190-191/225).

Despite anticipating later descriptions of reciprocity in dialogue, Merleau-Ponty does not ultimately take up his call to 'restore' the theoretical status of intersubjective experience in the Phenomenology. Despite the potential of these observations, the chapter on 'Others' claims that even if the subject is not responsible for constituting intersubjective experience, 'I am nevertheless the one through which these acts are lived' (374/416). The central role of subjectivity is clearly maintained here. Even if his early work already identified the need to do so, a more protracted study of dialogue was needed for Merleau-Ponty to revise this central commitment and adopt a genuinely intersubjective analysis of communication.

The Prose of the World meets this goal by moving beyond key tenets of the Phenomenology's account of sense-giving and understanding. The analysis of dialogue discloses an 'I speak' that refashions the 'I can' of the Phenomenology $(P W 17 / 26)$. While Merleau-Ponty draws on earlier analyses of embodiment, gesture, and expression, the 'I speak' of dialogue is more passive and receptive to determination by objects in its milieu than the 'I can' is. The 'I speak' ultimately provides a different interpretation of the Phenomenology's concept of 'motivation': in dialogue, we are solicited by meanings that only partially depend on us, which are sustained by the contributions of others. The reversal of roles in dialogue leads MerleauPonty to more radically question the subject's centrality for the analysis of meaningful phenomena (a basic assumption of the Phenomenology), resulting in incipient versions of tenets that will become key parts of his later account of meaning-comprehension. 


\subsection{Activity and Passivity}

The interpretation of dialogue also points toward a revised account of the concepts of 'activity' and 'passivity,' widely acknowledged to be central for his transition to ontological research (see Hughes 2013; Morris and Maclaren 2015; Carbone 2004, 1-14). The 1955 course on passivity is often identified as a key turning point for this account. As I argue, Prose of the World already anticipates basic features of this view.

A close look shows that the Phenomenology's discussion of activity and passivity cuts in two directions. Some descriptions of passivity suggest a continuity with active or goal-directed behaviour. Consider remarks about sleep. To fall asleep is to pass into an 'anonymous' sphere, no longer subject to the purview of motor intentional direction. Nevertheless, 'the sleeper is never completely enclosed in himself, never fully asleep' ( $P h P 167 / 202)$. The passive sleep state retains a link with activity because, as embodied agents, we can 'withdraw' from and resume active engagements according to certain situational conditions. More broadly, in waking life activity and passivity are 'geared into' one another: the subject passively accepts worldly conditions while actively responding to and shaping them (261/298). These descriptions suggest that activity and passivity are on a continuum, and that neither term is (strictly speaking) privileged.

But other remarks complicate this picture. First, Merleau-Ponty suggests that activity and passivity can also be understood in parallel to one another. The 'Temporality' chapter claims that the subject is 'simultaneously' active and passive because it is 'the sudden upsurge of time' (452/491). In addition to sleep or worldly motivation, passivity figures in temporal experience because subjects always bring their past into the present whenever they act in the world. Embodied habits are effectively acquired modes of behaviour, and habit always tacitly guides activity. However, Merleau-Ponty demurs on how subjects can be passive and active simultaneously. He acknowledges this while noting that even if contact with the past or future is not achieved by intellectual activity, and is effected through habituation, the 'passive synthesis of time [is] a term that is clearly not a solution, but merely a sign for designating a problem' (442/481). Whatever his solution to this problem is, it allows that activity and passivity are parallel to one another. This entails that they need not be continuous, but separate in kind, even if always co-present.

Second, Merleau-Ponty sometimes privileges activity over passivity, further undermining the claim that they are continuous, or equally important in experience. While temporal experience requires both terms, the tacit guidance of habit (or other passive modalities) is possible provided we actively take up some specific practical goal in the present (see Casey 1984). Further, the view that activity and passivity are 'simultaneous' rests on the assumption that subjectivity is an 'upsurge'. And even in sleep, memory, or aphonia, cases that ostensibly provide good evidence for parity between these two terms, any continuity underlying them is supported by bodily activity: a passive state is shown to maintain a connection to activity whenever the body 'signifies (in the active sense) beyond itself' (168/203). A passive sleep state is transformed into an active waking state through bodily 'transcendence', a paradigmatic activity. 
The discussion of dialogue helpfully clarifies these points. It rejects the view that activity and passivity are simultaneous (or parallel), and develops the implicit claim that they are continuous, affording equal weight to both. If speaker (subject) and listener (object) are in principle reversible, if each can lead and be led by the other, and if meaning in dialogue is formulated through openness to a conversational partner who co-constitutes our speech, then subjects cannot be active and passive at once. In addition to speakers and listeners' positions, a reversal of activity and passivity is also required by dialogue:

Between myself as speech and the other as speech, or more generally myself as expression and the other as expression, there is no longer that alternative that makes a rivalry of the relation between minds. I am not active only when speaking, but precede my thought in the listener; I am not passive while I listening, but speak according to... what the other is saying. Speaking is not just my own initiative, listening is not submitting to the initiative of the other. (PW 143-144/199-200)

While activity and passivity might be equally important for dialogue, they do not unfold parallel to one another. An ostensibly active engagement like speaking also presupposes elements of passivity within it. While speaking to another subject, I might also anticipate a possible response, which a focus on my speech will not detect. Similarly, listening to a speaker (a seemingly passive engagement) requires keen attention to what is being said, and counts as a distinctive kind of activity.

The Phenomenology held that active and passive elements could be found in various embodied engagements; but it required that they be different in kind. The text above, by contrast, suggests that activity and passivity are not separate in kind: "strictly speaking...[there is] an impossibility in maintaining the distinction between the active and the passive, between self and other' (18/27). A marginal note to the text adds that whereas 'listening and speaking' seem to be 'simple modalities of perception and movement,' the phenomenology of dialogue shows that activity and passivity cannot be reduced to earlier analyses of embodiment or perception. Dialogue requires 'recognition of the passive by the active and of the active by the passive, of the hearer by the speaker' (n.1 19-20/29). This mutual recognition guides subjects' expressions, and requires a more nuanced account of their active and passive behaviours. For example, a disapproving look from a listener usually results in a significant modification of a speaker's remarks. This often occurs with minimal awareness of the subtle modifications at work in a speaker's gestures and expressions, which remain active engagements, despite the passive elements discovered upon closer scrutiny. For these reasons, Merleau-Ponty maintains that activity in dialogue presupposes significant support from passivity, and that passivity is not mere submission to another's direction.

Activity and passivity, then, are now defined as 'degreed' concepts. Subjects are not either wholly active or passive (or both) when taking up roles in dialogue, which could support the earlier claim of simultaneity. On the whole, a listener remains in a largely passive modality, but also actively prepares the groundwork for a future reply. And even if a speaker actively expresses a view, she also passively anticipates possible responses from her conversational 
partner, and might begin modifying her claims accordingly. Listeners and speakers are not active and passive at once: instead, some activities contain passive elements, and vice versa.

The view that speakers cannot be active and passive simultaneously, together with the claim that subjects and objects in dialogue exchange positions, might suggest that dialogical experience (as Merleau-Ponty describes it) consists in a formulaic or mechanistic substitution of roles. Despite his reliance on binary categories (e.g. subject-object, active-passive), the view above points to a different model. Dialogue establishes a shared structure that effectively undermines the rigidity of circumscribed subject/object or active/passive relations. That there are degrees of activity and passivity, for example, entails that speakers or listeners are never merely subjects or objects in the classical sense. Speech supports conditions whereby active modalities are checked by more passive behaviours in others. Traditional categories like an actively determining subject, or a passively receptive object, quickly break down here, since participants in dialogue do not straightforwardly fall into or take turns occupying either category. To be sure, Merleau-Ponty is in the midst of reformulating his views, and continues to rely on classical divisions that occasionally hide the deeper upshot of his claims. While he uses terms like 'subject' or 'activity' to describe this multi-directional and shared model of meaning formation, speaking or listening have a novel expressive, intentional, and behavioural status that is not fully captured by these concepts.

By all accounts, Merleau-Ponty has moved closer to his later view of activity and passivity, often thought to originate in his 1954-1955 lectures (see Vallier 2015, 112-113). On this view, there is passivity 'in' and 'of' activity (VI 221/270, 264-265/312). While one can distinguish between more and less active or passive engagements, in either case it is necessary to posit a degree of passivity in what appear to be largely active engagements. Forgetting is one of Merleau-Ponty's most recurring examples of this relationship. Forgetting is understood as an activity 'in' passivity, since it is largely passive and is not directly undertaken by a subject. Nevertheless, (following Husserl) forgetting actively forms or constitutes a determinate content that can be accessed later. Hence, seemingly passive forgetfulness still actively preserves the past (IP 197/256). ${ }^{18}$

The evidence above suggests that an activity 'in' passivity is at work in dialogue. Even if Merleau-Ponty does not define activity and passivity in these terms in Prose of the World, his account clearly moves beyond the claims that activity and passivity are distinct in kind and unfold parallel to one another. Instead, he holds that there are degrees of activity in passivity, a claim that is worked out in subsequent lecture courses.

\subsection{Intentional 'Transgression' and 'Encroachment'}

Merleau-Ponty's descriptions of the reversal of roles in dialogue also hint at an underlying account of intentionality enabling this shift in stance $(S 94 / 153)$. In later writings he develops a distinctive view of intentionality that extends the account of 'operative intentionality' offered in the Phenomenology (PhP 1xxxii/18, 441/480, 453/492). While he sometimes claims to be uninterested in articulating such a view, evidence shows that he intends to offer a refined

\footnotetext{
${ }^{18}$ See Husserl 1970, 368-369. Merleau-Ponty adopts a similar view (S 59/95).
} 
account of intentionality (and constitution), variously called 'latent' or 'operative' intentionality. ${ }^{19}$ The phenomenology of dialogue was particularly important for the development of this view.

I cannot consider this view in detail here, but two key features should be noted. 'Transgression' (transgression) and 'encroachment' (empiétement) are both central to the account of intentionality modelled after the flesh. ${ }^{20}$ Subjects 'encroach' on objects or other subjects when passing into the sphere of what they can be directed to, alternatively, when they become an intentional object. The reversibility between seer and seen is a characteristic example of encroachment. 'Transgression' is a closely related concept that describes a similar result. ${ }^{21}$ This concept takes up Husserl's term Überschreitung, which Merleau-Ponty uses to describe his reformulated account of subject-object relations (likening them to intentional encroachment) (VI 200/250; see also Husserl 1970 §36). A note from May 1960 claims that the subject ('the flesh of the body') can extend beyond its circumscribed role as intentional pole, taking that of its object ('the flesh of the world') (VI 248/297). This shift produces a relation of intentional transgression.

The importance of these terms for Merleau-Ponty's later account of intentionality has been noted (see de Saint Aubert 2004), but the central role that analyses of dialogue played for its development remains unexamined. Early in the chapter on dialogue, he claims that 'speech accomplishes the anticipation, encroachment [empiétement], transgression [transgression], the violent operation by which I build within the figure...' ( $P W 131-132 / 183)$. This suggests that transgression in speech is liable to generate novel meanings. Having offered a description of dialogue, he concludes that 'we encroach [nous empiétons] upon one another insofar as we belong to the same cultural world, and first of all to the same language, and my acts of expression and those of the other bud [relèvent] from the same institution' (139/194). This remark suggests that encroachment in language is a special version of a broader structure or 'institution,' which has a wider cultural or historical status.

While the implications of this view are not considered in the manuscript, unpublished material suggests Merleau-Ponty took his reflections on dialogue to directly result in a new account of intentionality. Associated research notes define '[s]peech as autonomous intentionality,' and claim that '[s]peech is constitutional contact' (BNF Ms. Vol. III 186/1; 185r). Expression in dialogue demonstrates the need to define 'speech as the constitution of a style of the speaker and the listener,' and leads us to recognize a 'gestalt' form instantiating itself in communication (207r/1). 'Style' was an important part of the Phenomenology's account of intersubjective communication. That text argued that meaning in speech is incarnated in speakers' embodied projects (or 'gestures'), which cannot be understood by appeal to representation, or in light of physical facts like spatio-temporal location. Instead, speech has an 'affective' or lived value ( $P h P$ 188/222). Expression is characterized by a 'sonorous and articulatory style', that is, an embodied structure whose meaning is a function of how it is expressed (186/220). We understand another speaker's intentions by attempting to decode the meanings given by their expressive style (189-224). Now even if similar claims are found in later descriptions, the Phenomenology's account of style differs from dialogical style in a key way. Earlier writings ultimately analyzed style as a modification of embodied expressive capacities

\footnotetext{
${ }^{19}$ See $S$ 165/269 ff., VI 173/224-225, 238-239/287-288, 244/293. Cf. Butler 2005, 181; Dillon 1988, 85.

${ }^{20}$ For the first see VI 200/250, 203/253, 248/297; for the second VI 218/267, 238-239/287-288.

${ }^{21}$ See de Saint Aubert 2013, 157 for the link between transgression and encroachment.
} 
$(145 / 179,425 / 464,455-456 / 495)$. Style in speech was defined as a 'modulation' of bodily expression (186/220). While dialogue remains an embodied activity, dialogical style and its attendant account of intentionality are thought to have an autonomous status that cannot be reduced to or explained by bodily style. The observations above suggest that intentionality in speech is of a different order than that of perception or embodiment, and that intentional directedness is facilitated by the structure of dialogue itself.

The descriptions above show that dialogue establishes a structure whereby subject and object roles are in principle reversible. This has important implications for intentionality, because it points toward a view of directedness on which objects (listeners) can take on the role of subjects (speakers). Alternatively, it shows that a theory of intentionality must also accommodate the possibility that the objects of our gaze or expression guide directedness as much as vision or speech themselves. Dialogue reveals this by showing how a spontaneous, 'auto-organization of the given' enables us to follow and respond to the guidance of subjects who will in turn be directed by us. Hence, intentionality cannot be a uni-directional relation that originates in subjects and moves out toward objects or the world; objects are also sources of intentional direction. These observations lead Merleau-Ponty to define 'intentional transgression, coupling [l'accouplement] by language,' as 'a reciprocity of speaking and listening' (BNF Ms. Vol. III 192r). Dialogue offers a prime example of intentional transgression and encroachment.

As Emmanuel de Saint Aubert argues, encroachment was already a focus of MerleauPonty's research in the late 1940s. Of particular importance for this work was a protracted reading of Beauvoir, which led Merleau-Ponty to develop a view of encroachment on which subjects can 'pass into' one another, in active and passive modalities (de Saint Aubert 2014, 64, $62,81-82$ ). More specifically, Beauvoir's account of encroachment in experiences of freedom and love as described in Le sang des autres led Merleau-Ponty to conclude that the concept is central to the theory of expression and embodiment (de Saint Aubert 2014 66; see also 72 passim).

This evidence demonstrates that earlier discussions of encroachment (and transgression) undoubtedly laid the groundwork for later research, and became central to Merleau-Ponty's understanding of intersubjectivity. As de Saint Aubert notes, however, insights from these investigations are applied to philosophical concerns falling within a familiar existentialist framework. Conversely, the conclusions drawn from later dialogical versions of encroachment are developed under the auspices of a different model of sense-making, expression, and experience. This suggests that encroachment in speech had a special significance for MerleauPonty's transition to ontological investigations. That dialogical versions of encroachment are more frequently associated with other novel, proto-ontological tenets further suggests they exercised a decisive influence on the trajectory of later research. For example, dialogical speech shows that 'language...admits of a truth not conditioned by the decisive acts of human beings' (193r/3). Intentionality in language points toward a view of truth that is not analyzable solely in terms of a subject's activity. Recall that the goal of articulating a new view of truth is a guiding concern of Merleau-Ponty's ontological projects. Until this point, he held that a subject's intending and perceiving of the world is the ultimate source of truth $(P h P \operatorname{lxx} / 16-17 ; \operatorname{Pr} P$ 11/43). The phenomenology of dialogue reveals a different ground of truth, and indicates that a non subject-centric analysis is needed to understand it. 
This observation suggests an additional consequence of intentional encroachment uniquely connected to speech. Despite his reliance on some Husserlian terminology, MerleauPonty thinks his own view of intentional encroachment in speech undermines accounts reliant on a view of 'contemplative consciousness' (BNF Ms. Vol. III 207r/1). The 'intentional transgression of speech' is an 'an intention of my phenomenal body, of "another body," [...], of my speech and another's speech' unlike that found in Husserl (209r/3). ${ }^{22}$ In this vein, he asks: '[n] ow how do the 2 [subjects] understand one another? L'Ueberschreiten or intentional transgression. How to understand this across constitution, Sinngebung, Auffasung als? It is impossible. ${ }^{23}$

While similar criticisms of Husserl are found in the Phenomenology, the nascent analysis of dialogue also offers an opportunity to modify Merleau-Ponty's own earlier positions, which these notes sometime criticize together with classical phenomenological views. This move marks an important shift in focus toward a linguistically-informed view of intentionality. MerleauPonty claims that his study of language discloses a 'consciousness that presupposes language [le langage],' namely, a 'consciousness-unconsciousness that is perception' (218v). The point is not that we are unaware of intentional directedness while speaking. Rather, we could not be directed to meaningful contents in dialogue without the help of another speaker. The dialogical relationship enabling this, moreover, is not the result of subjective activity. It depends on a quasiunconscious or tacit form of intentional directedness that originates in a source partially external to us. The very idea of intentionality, once analyzable with reference to one subject's motor projects, has been revised.

These remarks show that attention to dialogue coincides with a conceptual shift in Merleau-Ponty's understanding of intentionality, revealing a turn to a different set of philosophical presuppositions. The criticisms above showcase early versions of rejoinders to the Phenomenology's account of intentionality in Le monde sensible et le monde de l'expression (MSME 48-51; see also VI 189-190/240-241, 243/291-293). Further, the claim that perceptual intentionality presupposes an intentional use of language indicates an important development from the Phenomenology, which held that language is secondary to or 'founded' on perception (PhP 131/162-163, 414/454, 425/465). Now, language is thought to be as significant as perception. Further, the nature of intentional directedness in dialogue seems to more successfully meet an original goal of the Phenomenology, namely, the undermining of a subjectivist view of intentionality. While discussing intentional encroachment in language, Merleau-Ponty claims that 'this is what I wanted to say in showing in the Ph.P. that the Sinngebung is not ours' (BNF Ms. Vol. III 218v). Instead of 'motricity' or 'ambiguity,' this goal may be met using observations drawn from intentional encroachment in language.

Later texts confirm the central influence of dialogical expression on this view of intentionality (VI 203/253, 224/273). Intentionality in speech is thought to have direct ontological bearing, irreducible to earlier existential analyses of embodiment, which discloses the 'common tissue of which we are made.' But it generalizes beyond intersubjective

\footnotetext{
${ }^{22}$ See de Saint Aubert 2013, 153-161 for differences between these two accounts.

${ }^{23}$ Instead of relying on Husserl's concept of Paarung, Merleau-Ponty invokes his own view of linguistic 'intentional transgression' ( $S$ 94/153).
} 
communication, and can purportedly explain the écart, 'brute' being, and the 'Ineinander,' a recurring cluster of terms in Merleau-Ponty's later work. This general 'ontological' view of intentionality, however, first originates in dialogue (218/267).

\section{§4. The Explicit Ontological Implications of Dialogue}

By anticipating views of intentionality, activity and passivity, reversibility and perceptual narcissism, the evidence above testifies to the implicit ontological import of Merleau-Ponty's phenomenology of dialogue. In the early 1950s, however, he was already aware of its broader consequences: '[t]he experience of living language has sufficiently convinced us that it has a metaphysical significance...' $(P W 38-39 / 54-55)$. Language is identified as a privileged mode or 'vehicle' for the experience of truth, an all-important ontological topic (129/180-181). Published work from this period claims that language is no mere regional problem $(S 88 / 142)$, that speech has an ontological bearing of its own (86/140), that the phenomenology of language teaches us 'a new conception of the being of language,' and that 'language is much more like a sort of being than a means' (43/69).

These conclusions indicate that he was already developing different accounts of truth and meaning while writing Prose of the World ${ }^{24}$ As I noted in $\$ 2$, sense, intersubjectivity, and truth are ontological leitmotifs. Remarks from Prose of the World and related texts show that MerleauPonty saw dialogue, more than other domains of inquiry (e.g. perception, literature), as an exemplar of a distinctively intersubjective structure of meaning-formation, truth, and being. His analyses of speech attempt 'to awaken a carnal relation [rapport charnel] to the world and the other,' and disclose 'our first insertion into the world and into the true [le vrai]' (PW 139/193). The 'carnal relation,' a recurring concept in later texts, refers to a general structure obtaining in experience, which guides perception, language, and thought, and which is eventually associated with 'the flesh' (VI 83-84/114, 208/258, 269/317). Guided by this structure, 'as speaking subjects we continue, we resume the same effort, older than us, upon which we are grafted [entés] to one another, which is the manifestation, the becoming of truth [le devenir de la vérité]' ( $P W$ $144 / 200)$.

In addition to disclosing a view of meaning-transformation that 'cannot be grasped in terms of contemplation,' and offering resources to identify the limits of phenomenological concepts traditionally employed in investigations of meaning, truth, and being, the observations above also license important broader conclusions (144/200). According to Merleau-Ponty, the structures of dialogue are always somewhat particular, insofar as they are tailored to a specific encounter between speaking subjects. But they also have a 'universality' (142/197) that cannot be 'assigned' a specific 'place' (141/196-197). Studying dialogue reveals a 'foundation of truth,' but one not limited solely to intersubjective communication (144/200). The mode of senseformation in speech is not produced by specific dialogical encounters. Instead, the latter are thought to exemplify or exhibit the former. Hence, this research was understood as a window into philosophical themes extending beyond the study of communication.

\footnotetext{
${ }^{24}$ Some remarks even identify $O . V$. and $P W$ (BNF Ms. Vol. III 189, 218r, 237; VIII 115/2).
} 
In addition to these remarks, associated research notes also shed light on a wider, budding ontological structure:

It is in language and only by way of language that one can understand how [speaking is listening] consciousnesses exchange their roles, and how a being for many is constituted [comment se constitue un être à plusieurs], because one understands there how speaking is listening and listening is speaking. From the perspective of consciousness, this is not thinkable. (BNF Ms. Vol. III, 197r) ${ }^{25}$

This confirms that speech exemplifies a distinctive form of intersubjective constitution, and that the study of language is best positioned to disclose it. Intersubjective constitution requires the multi-directional participation of subjects (an 'exchange of roles'). The tenets discussed above (§§3.1-3.3) are prime exemplars of this process. Undoubtedly, speech is an embodied activity, whose analysis profits from the Phenomenology's insights. Other domains of inquiry like empirical linguistics or the philosophy of literature also shed light on intersubjectivity and other ontological themes. But dialogue goes further: 'the body announces, by its own magic, a much greater wonder [merveille] that is accomplished by speech' (224). As a quintessentially intersubjective experience, dialogue clarifies intersubjective meaning-formation better than analytical tools focused on first-personal experience (perceptual or otherwise). The study of speech, then, was decisive for bringing an intersubjective focus in ontology to prominence.

Accordingly, Merleau-Ponty increasingly emphasizes the importance of 'the intersubjective thing' (S 173/282). An early statement of plans for ontological research identifies the need to shift analytical focus to a non subject-centric, 'lateral,' 'divergent,' or 'bi-directional genesis' of meaning (IP 133/178). But an entity whose meaning is generated intersubjectively cannot be adequately understood within the Phenomenology's conceptual framework (136/182). Unsurprisingly, this claim follows research into dialogue, which showed that intersubjective meaning-constitution unfolds in ways that subject-centric analyses cannot fully grasp. An analysis of this sort of entity is a recurring goal across Merleau-Ponty's later work, which strives to understand how objects can 'have another sense than that which we are in a position to recognize in them' (VI 94/127). Whatever their more local aims might be, the concepts of 'reversibility', 'dimensionality', 'brute' being, the 'écart' and 'the flesh' are deployed to probe this intersubjective domain of meaning.

\section{§5. Conclusion}

I have argued that the phenomenology of dialogue provides Merleau-Ponty with exceptional models of divergent meaning-formation, truth, activity and passivity, intentionality, and related concepts that he will later develop in more detail. The central importance of intersubjectivity for his ontology only confirms the formative role that reflections on dialogue played for its development.

In stressing the importance of dialogue, I have allowed for different interpretations of what sense, truth, or being ultimately amount to. Except for the constraint that interpretations of

\footnotetext{
${ }^{25}$ Noble 2014, 225 likens this description to the concept of 'Ineinander', but does not develop the link with dialogue.
} 
these terms recognizes the important role of intersubjectivity, one could accept the basic conclusions of my argument and privilege a range of conceptual influences and definitions of Merleau-Ponty's ontology. Dialogue certainly motivated a shift in focus to intersubjectivity; but this research anticipates later concepts only in outline. The influence of writers and thinkers from Hegel to Sartre, of the philosophy of history and nature, etc., remains to be specified. More must be said to understand Merleau-Ponty's later thought: but the centrality of intersubjectivity and sense will be basic to any analysis of its substantive commitments.

It is clear, however, that language plays a key role for its genesis and development. This influence is acknowledged throughout his later writings. For example, Merleau-Ponty claims that language is 'in a sense everything' and is a 'special domain' for ontology (VI 155/201, 117/154155). ${ }^{26}$ While extant sections of The Visible and the Invisible do not contain extensive analyses of language, the evidence above partly clarifies the motivation behind these remarks. MerleauPonty attaches ontological weight to language because his inquiries into dialogue served as an early testing ground for subsequent ontological research. ${ }^{27}$

Finally, this interpretation shows that Merleau-Ponty's later work in no way 'abandons' his earlier projects. ${ }^{28}$ Despite significant differences in the basic aims of the Phenomenology and The Visible and the Invisible, the clear development of concepts implicit in research from the early 1950s suggests that this view must be reconsidered. Surely, the incipient nature of these inquiries does not justify the view that he maintains or unpacks largely formulated conclusions or 'theses' ( $c f$. Dillon 1988). Still, this reading allows us to recognize a range of influences, while observing an underlying continuity of focus. A concern with the topics of intersubjectivity, sense, and truth remains constant throughout the developments in Merleau-Ponty's ontological research, which testifies to the catalytic role of dialogue for the trajectory of his later thought. ${ }^{29}$

\section{BIBLIOGRAPHY}

Alloa, Emmanuel. 2009. "La chair comme diacritique incarné." Chiasmi International 11: 249-262.

Barbaras, Renaud. 2004. The Being of the Phenomenon: Merleau-Ponty's Ontology. Translated by Leonard Lawlor and Ted Toadvine. Indianapolis: Indiana University Press.

Bonan, Ronald. 2001. La dimension commune: Le problème de l'intersubjectivité dans la philosophie de Merleau-Ponty. Volume 1. Paris: Éditions L'Harmattan.

\footnotetext{
${ }^{26}$ See also VI 102/136-137, 117 n.1/154*, 118/156, 126/165, 201/252.

${ }^{27}$ Even if it claims that nature is the 'privileged expression' of ontology, a 1959-1960 course identifies the formative role of language ( $N 204 / 265 ; 220 / 282)$.

${ }^{28}$ See Lefort's interpretation $(P W \mathrm{i} / \mathrm{xi}$, ix-xi/xvii-xviii).

${ }^{29}$ I would like to thank this journal's anonymous reviewers, and audiences at the 2015 meetings of SPEP and the Merleau-Ponty Circle, for their helpful comments. I would also like to acknowledge the Social Sciences and Humanities Research Council of Canada, which generously supported this research.
} 
Butler, Judith. 2005. "Merleau-Ponty and the Touch of Malebranche.” In The Cambridge Companion to Merleau-Ponty, edited by Taylor Carman and Mark B.N. Hansen, 181-205. Cambridge: Cambridge University Press.

Casey, Edward S. 1984. "Habitual Memory and Body Memory in Merleau-Ponty." Man and World 17: 279-297.

Carbone, Mauro. 2004. The Thinking of the Sensible: Merleau-Ponty's A-Philosophy. Evanston: Northwestern University Press.

Dastur, Françoise. 2000. "World, Flesh, Vision." In Chiasms: Merleau-Ponty's Notion of Flesh, Edited by Fred Evans and Leonard Lawlor, 23-50. Albany: SUNY Press.

Dillon, M.C. 1988. Merleau-Ponty's Ontology. Bloomington: Indiana University Press.

Hughes, Fiona. 2016. "Reversibility and Chiasm: False Equivalents? An Alternative Approach to Understanding Difference in Merleau-Ponty's Late Philosophy." British Journal for the History of Philosophy. DOI: http://dx.doi.org/10.1080/09608788.2016.1225565

---- 2013. “A Passivity Prior to Passive and Active: Merleau-Ponty's Re-reading of the Freudian Unconscious and Looking at Lascaux.” Mind, 122.486: 419-450.

Husserl, Edmund. 1970. The Crisis of the European Sciences and Transcendental Phenomenology. Translated by David Carr. Evanston: Northwestern University Press.

Kearney, Richard. 2013. "Ecrire la Chair: 1'expression diacritique chez Merleau-Ponty." Chiasmi International 15: 183-198.

Landes, Donald A. 2013. Merleau-Ponty and the Paradoxes of Expression. New York: Bloomsbury. Lawlor, Leonard. 1999. "The End of Ontology." Chiasmi International 1: 233-251.

Madison, Gary Brent. 1981. The Phenomenology Of Merleau Ponty: A Search For The Limits Of Consciousness. Translated by Gary Brent Madison. Athens: Ohio University Press.

Merleau-Ponty, Maurice. 1945. Phénoménologie de la perception. Paris: Librairie Gallimard.

---- 1948. Sens et Non-Sens. Paris: Les Éditions Nagel.

---- 1960. Signes. Paris: Gallimard, 1960.

---- 1964. Signs. Translated by Richard C. McCleary. Evanston: Northwestern University Press.

---- 1964. Sense and Non-Sense. Translated by Hubert L. Dreyfus and Patricia Allen Dreyfus.

Evanston: Northwestern University Press.

---- 1964. The Primacy of Perception. Translated by James Edie. Evanston: Northwestern University Press.

---- 1964. Le visible et l'invisible. Texte établi par Claude Lefort. Paris: Éditions Gallimard.

---- 1968. The Visible and the Invisible. Translated by Alphonso Lingis. Evanston: Northwestern University Press. 
---- 1968. Résumés de cours. Collège de France 1952-1960. Paris: Gallimard.

---- 1969. La Prose du monde. Texte Établi par Claude Lefort. Paris: Éditions Gallimard.

---- 1970. Themes from the Lectures at the Collège de France, 1952-1960. Translated by John

O'Neill. Evanston: Northwestern University Press.

--- 1973. The Prose of the World. Translated by John O'Neill. Evanston: Northwestern

University Press.

---- 1995. La nature: Notes, cours de Collège de France. Paris: Éditions du Seuil.

---- 1996a. Notes de cours au Collège de France, 1959-1960. Texte établi par Stephanie Menasé.

Paris: Éditions Gallimard.

---- 1996b. Le primat de la perception et ses conséquences philosophiques. Lagrasse: Éditions Verdier.

---- 2003a. L'Institution-La passivité: Notes de cours au Collège de France (1954-1955). Paris: Éditions Bellin.

---- 2003b. Nature: Course Notes from the Collège de France. Translated Robert Vallier. Evanston: Northwestern.

---- 2010a. Institution and Passivity: Course Notes from the Collège de France (1954-1955). Translated by Leonard Lawlor and Heith Massey. Evanston: Northwestern University Press.

---- 2010b. Child Psychology and Pedagogy: The Sorbonne Lectures 1949-1952. Translated by Talia Welsh. Evanston: Northwestern University Press.

---- 2011. Le Monde Sensible et le Monde de L'expression. Cours au Collége de France, Notes 1953. Texte établi et annoté par Emmanuel de Saint Aubert et Stefan Kristensen. Genève: MetisPresses.

---- 2012. Phenomenology of Perception. Translated by Donald Landes. New York: Routledge.

---- Bibliothèque Nationale de France, Department of Manuscripts. NAF 26986. Manuscript Volume III: La prose du monde.

---- Bibliothèque Nationale de France, Department of Manuscripts. NAF 26989. Manuscript Volume VI: Projets de 1958-Projet «Être et monde».

---- Bibliothèque Nationale de France, Department of Manuscripts. NAF 26991. Manuscript Volume VIII: Livre en project, 1958-1960.

Moran, Dermot. 2010. "Sartre on Embodiment, Touch, and the "Double Sensation"." Philosophy Today 54: 135-141.

Morris, David. 2010. "The Enigma of Reversibility and the Genesis of Sense in Merleau-Ponty." Continental Philosophy Review 43: 141-165.

Morris, David and Maclaren, Kym. 2015. Time, Memory, Institution: Merleau-Ponty's New Ontology of Self. Athens: Ohio University Press.

Noble, Stephen. A. 2014. Silence et Langage: Genèse de la phénoménologie de Merleau-Ponty au seuil de l'ontologie. Leiden: Brill.

Richir, Marc. 1998. "Le sensible dans le rêve.” In Merleau-Ponty - Notes de cours sur l'Origine de la Géométrie de Husserl--suivi de recherches sur la phénoménologie de MerleauPonty, Edited by Renaud Barbaras, 239-254. Paris: Presses Universitaires de France. 
Robert, Franck. 2005. Phénoménologie et ontologie. Merleau-Ponty lecteur de Husserl et Heidegger. Paris: Éditions L'Harmattan.

De Saint Aubert, Emmanuel. 2004. Du lien des êtres aux éléments de l'être: Merleau-Ponty au tournant des années 1945-1951. Paris: Vrin.

---- 2005. Le scénario cartésien: recherches sur la formation et la cohérence de l'intention philosophique de Merleau-Ponty. Paris: Vrin.

---- 2006. Vers une ontologie indirecte: sources et enjeux critiques de l'appel à l'ontologie chez Merleau-Ponty. Paris: Vrin.

---- 2008. Maurice Merleau-Ponty. Paris: Éditions Hermann.

---- 2013. Etre et Chair I. Du corps au désir: l'habilitation ontologique de la chair. Paris: Vrin.

Silverman, Hugh J. 1979. "Merleau-Ponty on Language and Communication (1947-1948)." Research In Phenomenology 9.1: 168-181.

Stawarska, Beata. 2013. "Uncanny Errors, Productive Contresens. Merleau-Ponty's Phenomenological Appropriation of Ferdinand de Saussure's General Linguistics." Chiasmi International 15: 151-165.

Thierry, Yves. 1987. Du corps parlant. Paris: Ousia.

Vallier, Robert. 2005. "Memory--of the Future: Institution and Memory in the Later Merleau-Ponty." In Time, Memory, Institution: Merleau-Ponty's New Ontology of Self, Edited by David Morris and Kym Maclaren. Athens: Ohio University Press. 